\title{
What Are We Waiting For? It's Time to Regulate Paralegals in Canada
}

\section{Lisa Trabucco*}

Law societies in Canada have long been granted the privilege of self-regulation by the state - a privilege that comes with a statutory duty to govern in the public interest. There exists an access to justice crisis in this country. More must be done to address unmet legal needs. There is nothing new in this, but law societies across Canada are reluctant to implement at least one ready solution. Ontario introduced paralegal regulation over ten years ago with the promise that it would increase access to justice. Evidence suggests that it has done so. Yet no other Canadian jurisdiction is prepared to regulate paralegals as independent providers of legal services. Law societies' continued resistance to the regulation of paralegals is contrary to the public interest. This paper argues that to alleviate the access to justice crisis, it is time to regulate paralegals.

L'État accorde depuis longtemps aux barreaux du Canada le privilège de l'autoréglementation, lequel privilège est toutefois assorti de l'obligation de gouverner dans l'intérêt public. Or, notre pays est miné par une crise en ce qui concerne l'accès à la justice. Il faut en faire davantage pour répondre aux besoins juridiques non satisfaits. Cette réalité n'est pas nouvelle, mais les barreaux de l'ensemble du Canada sont réticents à mettre en ouvre au moins une solution fonctionnelle. L'Ontario a adopté un règlement sur les parajuristes voilà plus de dix ans en promettant que ce règlement permettrait d'accroître l'accès à la justice. Il semble que ce soit effectivement le cas. Pourtant, aucun autre territoire canadien n'est disposé à réglementer la profession des parajuristes à titre de prestataires indépendants de services juridiques. La réticence continue des barreaux à s'engager dans cette voie va à l'encontre de l'intérêt public. Dans ce texte, l'auteure soutient qu'afin d'atténuer la crise de l'accès à la justice, il est temps de réglementer les parajuristes

\section{INTRODUCTION}

There is an access to justice problem in Canada. ${ }^{1}$ The regulation of paralegals in Ontario was billed as a solution to that problem for Ontarians. Paralegals are licensed in Ontario to provide legal services directly

* Visiting Assistant Professor, Faculty of Law, University of Windsor.

1 Action Committee on Access to Justice in Civil and Family Matters, Access to Civil and Family Justice: A Roadmap For Change, (Toronto: Action Committee on Access to Justice in Civil and Family Matters, 2013) at 1 [Roadmap]; Canadian Bar Association, Canada's Crisis in Access to Justice: Submission to the United Nations Committee on Economic, Social and Cultural Rights (Ottawa: CBA, 2006) at 1, online: $<$ http://socialrightscura.ca/documents/CESCRSubmissions/canadianbarassociation.pdf>; Canadian Bar Association Access to Justice Committee, Equal Justice: Balancing the Scales (Ottawa: CBA, 2013) at 5, online:

$<$ https://www.lsuc.on.ca/uploadedFiles/For_the_Public/About_the_Law_Society/Convocation_Decisions/2014/CBA_eq 
to the public, for a fee, independent of lawyers. ${ }^{2}$ After more than twenty years of an uneasy coexistence between lawyers and non-lawyers who independently provided a range of legal services in an unregulated market, the Ontario government introduced paralegal regulation in 2007 with the promise that regulation would increase access to justice by ensuring paralegal competence, increasing choice of qualified legal services provider, and making legal services more affordable. ${ }^{3}$ The government granted to Ontario's law society (which had for over 200 years been the self-regulating body of lawyers only) regulatory authority over paralegals. ${ }^{4}$ For some, this was akin to "asking the fox to watch the chickens." 5 But despite, or because of, regulation by the Law Society of Ontario (LSO), there is evidence that paralegal regulation has fulfilled the government's promise of increased access to justice.

Outside Ontario, the term "paralegal" is confusing and ambiguous. In most other jurisdictions in Canada, a paralegal is a non-lawyer who works only under lawyer supervision, and does not provide legal services directly to the public, for a fee. These paralegals might also be referred to as legal assistants or law clerks. ${ }^{6}$ Others - unregulated non-lawyers - who provide legal services independently and pursuant to statutory authority, are mainly referred to as agents or consultants, but many are also referred to, more generally, as paralegals. ${ }^{7}$

The legal profession in Canada is self-governing. Law societies have a statutory mandate to regulate in and protect the public interest. ${ }^{8}$ Access to justice, and particularly to legal services, serves the public interest. In Ontario, revisions to the Law Society Act that introduced paralegal regulation imposed an

ual justice.pdf>; Trevor C Farrow, "What is Access to Justice?” (2014) 51 Osgoode Hall LJ 957 at $962-963$ [CBA "Equal Justice"].

2 Ron W Ianni, Report of the Task Force on Paralegals (Toronto: Ontario Ministry of the Attorney General, 1990) at xi [Ianni Report]; Law Society Act, RSO 1990, L-8, s 1(1) and By-Law 4.

3 Ontario, Legislative Assembly, Official Report of Debates (Hansard), $2^{\text {nd }}$ Sess, $38^{\text {th }}$ Leg, Bill 14, Access to Justice Act 2005, First Reading (26 October 2005).

4 The Law Society Act, RSO 1990, c L.8 provides for two categories of licensee: L1 for a barrister and solicitor, who is authorized to practise law in Ontario; and P1 for a person who is licensed to provide legal services (referred to as a paralegal although this term does not appear in the $A c t$ ).

5 Richard Mackie, "Law Society wants control over activities of paralegals", Globe and Mail (24 September 2004), online: $<$ globeandmail.com>; Timothy Appleby, "Draft legislation on way to regulate Ontario paralegals", Globe and Mail (1 November 2004), online: <globeandmail.com>. See also Ontario, Legislative Assembly, Official Report of Debates (Hansard), $2^{\text {nd }}$ Sess, $38^{\text {th }}$ Leg, (12 October 2006) ( $3^{\text {rd }}$ Reading, Ted Chudleigh, MPP Halton); and 16 October 2006) (3 $3^{\text {rd }}$ Reading, Gilles Bisson, MPP Timmins-James Bay).

6 The Canadian Association of Paralegals defines a "paralegal" as an individual qualified through education, training or work experience, who is employed or whose services have been retained by a legal professional, law firm, governmental agency, private or public corporation or other entity in a capacity or function which involves the performance, under the supervision of a legal professional, of substantive legal work ... requiring sufficient knowledge of legal concepts": online: <https://caplegal.ca/en/about/>.

$7 \quad$ Ibid. Some non-lawyers who provide legal services are differently regulated. For example, notaries in British Columbia are a self-regulating profession. Immigration consultants are regulated by a federal body: see Part III infra.

8 Legal Profession Act, SBC 1998, c 9, s 3; Legal Profession Act, RSA 2000, c L-8, s 49(1); Legal Profession Act, 1990, SS 1990-91, c L-10.1, s 3.1; Legal Profession Act, CCSM c L107, s 3(1); Legal Profession Act, SNS 2004, c 28, s 4(1); Law Society Act, 1996, SNB 1996, c 89, s 5; Legal Profession Act, RSPEI 1988, c L-6.1, s 4; Law Society Act, 1999 , SNL 1999, c L-9.1, s 18(1.1); Legal Profession Act, RSNWT 1988, c L-2, s 22(a); Legal Profession Act, RSNWT (Nu) 1988, c L-2, s 22(a); Legal Profession Act, RSY 2002, c 134, s 3; Law Society Act, RSO 1990, c L.8, s 4.2; Professional Code, CQLR c C-26, s 23. 
additional duty on the law society to facilitate access to justice. While other jurisdictions in Canada are considering the issue of paralegal regulation - some have debated the issue for decades - not one is yet prepared to regulate paralegals. Despite a lack of regulation, however, a wide range of paraprofessionals provide legal services across the country, meeting otherwise unmet legal needs. The relationship between an increased role for non-lawyers and enhanced access to justice has long been recognized, and evidence reveals that paralegal regulation (in Ontario) has increased access to justice. Law societies' reluctance to regulate paralegals is inconsistent with their duty to regulate in the public interest.

Part II discusses the legal profession's duty to regulate in the public interest and to ensure access to justice. It also examines the rationales for regulation, specifically quality assurance, choice of appropriate service provider, and cost of services. Part III canvasses law societies' perspectives and initiatives concerning paralegal regulation across Canada, and reveals not only a general reluctance to regulate but also unconvincing arguments for not doing so. Part IV sets out reasons why paralegals should be regulated - the existing scope of non-lawyer legal services provision, the acknowledged role that non-lawyers can play in providing access to justice, and evidence that paralegal regulation in Ontario has increased access to competent legal service providers - and suggests some features of a regulatory model. This paper concludes by arguing that it is time for law societies in Canada to regulate paralegals as a solution to the access to justice crisis.

\section{ACCESS TO JUSTICE AND REGULATION}

Access to justice is a basic right, not a privilege that should be afforded to some and not to others. ${ }^{9}$ Access to justice is linked to substantive justice through the enforcement of rights. ${ }^{10}$ The Supreme Court of Canada has stated that access to legal services is fundamentally important in any free and democratic society and in some cases, is essential to due process and a fair trial. ${ }^{11}$ Courts and tribunals play a "central and irreplaceable role" in maintaining a legal framework for resolving disputes ${ }^{12}$ and therefore legal representation matters. ${ }^{13}$ The inaccessibility of legal services remains a significant barrier to a fair and efficient justice system. ${ }^{14}$

Access to legal services has been identified as a priority to improve access to justice in Canada. ${ }^{15}$ Former Chief Justice of the Supreme Court of Canada, Beverly McLachlin, argues that a just society must provide its entire citizenry access to the courts and other tribunals so that they can resolve the legal issues

9 Former Ontario Attorney General Madeleine Meilleur, Keynote Remarks delivered at launch of Better Justice Together, Attorney General's Four-Year Access to Justice Strategy, Toronto, 18 November 2014, online:

$<$ https://www.attorneygeneral.jus.gov.on.ca/english/better_justice/speech.php>; The Rt Hon Beverly McLachlin, CJC

"Preserving Public Confidence in the Courts and the Legal Profession" (2003) 29 Man LJ 277 at 280.

10 Law Commission of Ontario, Increasing Access to Family Justice Through Comprehensive Entry Points and Inclusivity (Toronto: February 2013) at 15, online: <www.lco-cdo.org $>$.

11 Christie v British Columbia (Attorney General), 2007 SCC 21, [2007] 1 SCR 873, at para 23.

12 CBA, "Equal Justice", supra note 1 at 45.

13 Samreen Beg \& Lorne Sossin, "Should Legal Services Be Unbundled?" in MJ Trebilcock, Lorne Mitchell Sossin \& Anthony J Duggan, eds, Middle Income Access to Civil Justice (Toronto: University of Toronto Press, 2012) at 198.

14 Ibid.

15 Roadmap, supra note 1 at 14. 
that confront them. ${ }^{16}$ Accessibility includes the availability and affordability of legal advice and representation. ${ }^{17}$ For the purposes of this paper, the following definition of access to justice applies: Access refers to quality and affordable services provided by competent providers, and justice requires fair outcomes achieved through formal institutions of justice. ${ }^{18}$ Ron Ianni, who led Ontario's first task force on paralegals in the late 1980s, argued that without access to legal services, full and meaningful participation in a democratic society is illusory. ${ }^{19}$

Regulation in the public interest is both a statutory imperative and a professional obligation. The legal profession has been granted self-regulatory powers on the understanding that the profession will exercise those powers in the public interest. ${ }^{20}$ The public interest encompasses competition and consumer choice, quality services, competence of practitioners, protection of the public from unqualified and incompetent service providers, affordable services, the efficient use of resources, flexibility in service delivery, and access to services. ${ }^{21}$ Christine Parker argues that access to justice is inextricably tied to the regulation of the legal profession, ${ }^{22}$ and that lawyers stand at an awkward intersection between law and justice. ${ }^{23}$ Retired Supreme Court of Canada Justice Peter Cory, who proposed a paralegal regulatory framework for Ontario, argued that increasing justice in a manner that protects the public must be the aim of the legal profession and the goal of government. ${ }^{24}$

\section{A. Quality}

Law is a complex product and therefore, according to Gillian Hadfield, there are reasons to license and regulate its delivery to ensure quality. ${ }^{25}$ The central focus of regulation must be the community's need for quality legal services and not the profession's need to monopolize the delivery of those services. ${ }^{26}$ Licensing aims to ensure quality assurance at the gate. ${ }^{27}$ The Law Society of Alberta, which tolerates a

16 McLachlin, supra note 9 at 280.

17 Canadian Bar Association, Standing Committee on Access to Justice, Access to Justice Metrics: Discussion Paper (Ottawa: Canadian Bar Association, 2013) at 8.

18 This definition is derived from the World Justice Project's “civil justice factor": Mark David Agrast, Juan Carlos Botero \& Alejandro Ponce, "The World Justice Project Rule of Law Index” (Washington, DC: World Justice Project, 2011).

19 Ianni Report, supra note 2 at 13.

20 Federation of Law Societies of Canada, Model Code of Professional Conduct, Ottawa: FLSC, 2014 , at 8.

21 Tracey L Adams, "Professional Self-Regulation and the Public Interest in Canada" (Paper delivered at the ISA RC52 Interim Conference on Challenging Professionalism, The School of Economics and Management (ISEG), Lisbon, Portugal, 29 November 2013), online: <http://pascal. iseg. utl. pt/ socius/interim > at 16-23. See also Noel Semple, Legal Services Regulation at the Crossroads - Justitia's Legions (Cheltenham, UK: Edward Elgar, 2015 ) at 249.

22 Christine Parker, Just Lawyers: Regulation and Access to Justice (Oxford: Oxford University Press, 1999 ) at 143.

23 Ibid at 11.

24 The Honourable Peter deC Cory, A Framework for Regulating Paralegal Practice in Ontario (Ontario, Ministry of the Attorney General, 2000) at 5 [Cory Report].

25 Gillian Hadfield, "The Cost of Law: Promoting Access to Justice through the Corporate Practice of Law" (2012) Intl Rev L \& Econ 43 at 61-62.

26 Victor S Savino, Paralegalism in Canada: A Response to Unmet Needs in the Delivery of Legal Services (LLM Thesis, Dalhousie University, Faculty of Law, 1976) at 334.

27 Law Society of Upper Canada, Proposal for Revisions to Paralegal Licensing Examination (Toronto: LSUC Paralegal Standing Committee, October 2012) at para 18, online: <https://www.lsuc.on.ca/WorkArea/DownloadAsset.aspx?id=2147489875>. 
robust and unregulated non-lawyer legal services industry, nevertheless acknowledges that quality legal services can only be provided by trained, licensed, insured, ethical, and experienced legal professionals with duties of ongoing continuing professional training. ${ }^{28}$

Self-regulation's rationale is based on the notion that it provides a vehicle through which the quality of the service may be maintained in markets where the consumer cannot readily measure this quality himself. ${ }^{29}$ Justice Cory argued that licensing, which ensures adequate insurance provisions, a code of conduct, and the necessary discipline procedures, is essential to adequately protect the public from incompetent, unqualified and irresponsible non-lawyers. ${ }^{30}$ A law society, as regulator, can exercise extensive disciplinary powers, and the requirement of compulsory errors and omissions insurance provides a measure of security for the public against incompetent or unprofessional licensees. These safeguards do not exist in respect of and do not apply to unlicensed non-lawyers who provide legal services. ${ }^{31}$ Alice Woolley and Trevor Farrow argue that regulation has costs, but also significant benefits. ${ }^{32}$ They argue that since the market for legal services is notably imperfect, with the result that the forces of supply and demand cannot reliably ensure efficient prices or appropriate quality of services, some form of regulation to protect the public interest in ensuring the adequacy of legal services is required. ${ }^{33}$ Hadfield and Rhode argue that a principal reason to regulate professional services is to raise the likelihood that consumers of legal services receive quality services, since the ordinary regulated market does not adequately police quality. ${ }^{34}$ According to Woolley and Farrow, the important idea underlying licensing is that both the quality and availability of legal representation matter. ${ }^{35}$

\section{B. Choice}

The Competition Bureau of Canada believes that the range of activities reserved for lawyers must be justified by a clear social benefit, and that the public can be protected without affording lawyers complete exclusivity over all legal tasks. Law societies should neither prohibit related service providers from performing legal tasks nor limit their ability to do so unless there is compelling evidence of demonstrable harm to the public. ${ }^{36}$ Many have argued for a reorganization of legal services delivery. According to Devlin and Heffernan, many legal services could be supplied by others such as paralegals and competition might well increase both the possibility of lower prices and improve the quality of services. ${ }^{37}$ Almost 25

28 Law Society of Alberta, Alternative Delivery of Legal Services Committee, “Alternate Delivery of Legal Services Final Report" (Law Society of Alberta, February 2012) at 22 [LSA ADLSC, "Final Report" 2012].

29 Avner Shaked \& John Sutton, "The Self-Regulating Profession" (1981) 48 Rev Econ Studies 217 at 217.

30 Cory Report, supra note 24 at 25-26\&81.

31 Law Society of British Columbia v Bryfogle, 2006 BCSC 1092 at para 18.

32 Alice Woolley \& Trevor CW Farrow, “Addressing Access to Justice Through New Legal Service Providers: Opportunities and Challenges" (2016), 3 Texas A\&M L Rev 549 at 571.

33 Ibid, at 570-571.

34 Gillian K Hadfield \& Deborah L Rhode, "How to Regulate Legal Services to Promote Access, Innovation, and the Quality of Lawyering" (2016) 67 Hastings L J 1191 at 1199.

35 Woolley \& Farrow, supra note 32 at 570.

36 Canada, Competition Bureau, Self-Regulated Professions: Balancing Competition and Regulation (Ottawa: Industry Canada, 2007) at vii, online: <www.competitionbureau.gc.ca/eic/site/cb-bc.nsf/eng/02523.html $>$ [Competition Bureau, Self-Regulated] at 70 .

37 Richard F Devlin \& Porter Heffernan, “The End(s) of Self-Regulation?” (2008) 45 Alta L Rev 169 at 191. 
years before paralegal regulation was implemented in Ontario, Frederick Zemans argued that the use of non-lawyers in the delivery of legal services is one of the most important ways to ensure that the citizens who cannot afford lawyers' services are not denied access to justice. ${ }^{38}$ He argued that translating the ideal of equal access before the law into a reality requires opening the legal services market to alternative suppliers and entrusting those suppliers with the maximum degree of independence that is consistent with adequate and competent service. He further argued that the retention of monopolies which seek to curtail the scope of activities of alternative suppliers in the market for legal services unfairly prejudices the rights of non-lawyers who are providing competent services and, most of all, amounts to a serious denial of access to justice by depriving those whose need is greatest of the ability to assert their legal claims and to pursue their rights. ${ }^{39}$

Following her national study of self-represented litigants in Canada, Macfarlane called on policy makers and professional regulators to re-evaluate the historical reasons for the restriction of paralegal services in Canada, including "urgent reconsideration" of the types of assistance that can be offered by (licensed) paralegals, especially with family law matters. ${ }^{40}$ Parker argues that the development of new (non-lawyer) occupations to compete with lawyers in providing inexpensive legal advice and representation is a significant step toward improving access to justice at the lower end of the market. ${ }^{41}$ Like Parker, Hadfield argues in favour of a more open approach to legal markets that would allow for the licensing of multiple legal professions. ${ }^{42}$ Similarly, Semple argues that licensing multiple legal occupations is essential for access to justice. ${ }^{43}$

\section{Cost of Services}

There is a long-recognized and well-documented gap in affordable legal services in Canada and a need for access to legal assistance. ${ }^{44}$ Noel Semple argues that the scant attention that North American regulators have paid to price-related goals is disproportionate to the importance of service price for clients, and also disproportionate to "the pivotal role with which legal service price has played in impeding access to justice." 45 Meeting clients' interest in choice, Semple insists, includes the availability of different quality services at different price points. ${ }^{46}$ Macfarlane's study of self-represented litigants found that the majority of family law litigants in Ontario are self-represented, ${ }^{47}$ and across Ontario, British Columbia and Alberta, the most consistently cited reason for self-representation was the inability to afford to retain, or to continue

38 Frederick H Zemans, "The Non-lawyer as a Means of Providing Legal Services" in Robert G Evans \& Michael J Trebilcock, eds, Lawyers and the Consumer Interest (Toronto: Butterworths, 1982) 263 at 293.

39 Ibid.

40 Julie Macfarlane, The National Self-Represented Litigants Project: Identifying and Meeting the Needs of SelfRepresented Litigants - Final Report (May 2013) at 123 [Macfarlane, Final Report].

41 Parker, supra note 22 at 143 \& $156-157$.

42 Gillian K Hadfield, Rules for a Flat World - Why Humans Invented Law and How to Reinvent It for a Complex Global Economy (New York: Oxford University Press, 2017) at 243 [Hadfield, Rules].

43 Semple, supra note 21 at 288.

44 See Ontario Civil Legal Needs Project, Listening to Ontarians (Toronto: The Ontario Civil Legal Needs Project Steering Committee, May 2010) at 57 [Civil Legal Needs].

45 Semple, supra note 21 at 261

$46 \quad$ Ibid at 249.

47 Macfarlane, Final Report, supra note 40 at 33. 
to retain, legal counsel. ${ }^{48}$ This, too, is not new. Ianni found that the public retained the services of independent paralegals because many consumers of legal services believed that independent paralegals provided comparable or similar services to lawyers at less cost. ${ }^{49}$ David Stager considered whether paralegal regulation would result in low price, good quality, routine legal services delivery. ${ }^{50}$ Stager recognized that some factors would likely lead to higher fees than the unregulated market - training requirements would reduce the number of entrants, premiums for professional liability insurance would drive up the cost of services, and the demand for paralegal services would increase as public awareness and confidence grew. Other factors, however, would point to lower fees - the supply of services would increase, advertising would encourage competitive fee setting, and increased demand could result in economies of scale through the concentration of routine work by paralegals. ${ }^{51}$ According to Hadfield, solving the access to justice problem requires lawyers to share the field with other, less expensive nonlawyer professionals and organizations. ${ }^{52}$

\section{Too Much or Too Little Regulation?}

Regulation is both a gateway and a barrier. An inherent feature of self-regulation is a tendency toward self-interest, and the privilege of self-regulation provides a means to control and restrict competition. ${ }^{53}$ Richard Abel and other critics of self-regulation ${ }^{54}$ argue that it serves professional interests over the public interest by seeking to control the market for legal services, which increases the cost of and restricts access to those services. Both Rhode and Hadfield argue that some regulation is required as there is public interest in increased competition, and regulation of non-lawyers must balance the public interest in maximizing choice and minimizing harm. ${ }^{55}$

It is acknowledged that increased regulation is not necessarily compatible with increased access to justice. The Law Society of Alberta, for one, is not prepared to regulate paralegals for this reason. ${ }^{56}$ Ianni recognized that access to the legal system is dependent in large measure on the availability of legal services

48 Ibid at 39. See also Justice Annemarie E Bonkalo, Family Legal Services Review (Toronto: Ministry of the Attorney General, 2016), online: <https://www.attorneygeneral.jus.gov.on.ca/english/about/pubs/family_legal_services_review/> [Bonkalo Report].

49 Ianni Report, supra note 2 at 28-29.

50 David Stager, "Economic Issues Relating to the Possible Introduction of Independent Paralegals in Ontario" in Ianni Report, supra note 2, at 226.

$51 \quad$ Ibid at 232-233.

52 Gillian K Hadfield, "Lawyers, Make Room for Non-Lawyers" (November 25, 2012), online: $<\mathrm{http}: / /$ works.bepress.com/ghadfield/50/>.

53 Competition Bureau, Self-Regulated, supra note 36

54 Richard L Abel, "England and Wales: A Comparison of the Professional Projects of Barristers and Solicitors" in Richard L Abel \& Philip SC Lewis, eds, Lawyers in Society, Volume One, The Common Law World (Berkeley: University of California Press, 1988). See also Harry W Arthurs, Richard Weisman \& Frederick H Zemans, "Canadian Lawyers: A Peculiar Professionalism", in Abel \& Lewis, ibid at 123; Deborah L Rhode, "The Profession and the Public Interest", (2002) 54 Stanford LR 1501; Deborah L Rhode, "Professionalism in Perspective: Alternative Approaches to Nonlawyer Practice", (1996) 1 J Inst for Study Legal Ethics 197 at 204 [Rhode, "Perspective"].

55 Rhode, "Perspective”, supra note 54; Gillian Hadfield, “On Right-Regulating Legal Markets" (19 September 2011), online: <https://truthonthemarket.com/2011/09/19/gillian-hadfield-on-right-regulating-legal-markets/> [Hadfield, "Right-Regulating"].

56 See Part III, infra. 
within the system and that generally, the more a service is regulated or controlled the less accessible it becomes. ${ }^{57}$ Nevertheless, Ianni recommended "a least intrusive necessary" paralegal regulatory model consistent with the public's need for greater access to legal services along with some protection against possible abuses in the delivery of those services. ${ }^{58}$

Hadfield is of the view that the legal profession is not only over-regulated but also under-regulated - it is overly protective of lawyers' interests and insufficiently protective of the public's interest in an accessible, innovative and efficient legal system. ${ }^{59}$ While there is an argument to be made for less rather than more regulation, the status quo does not support this argument. The status quo - in which some statutes, including statutes governing the legal profession, authorize unregulated non-lawyers to provide some legal services that do not infringe on lawyers' practice - is not meeting the legal needs of ordinary Canadians. Semple argues that the status quo regulatory model - professionalist-independent regulation is itself an impediment to access to justice, and argues for regulatory reform rather than no regulation at all. ${ }^{60}$ Indeed, law societies across Canada agree that regulatory reform is required to address the access to justice problem. The focus should therefore not be on whether to regulate or not, but on the design of the regulatory model. The Competition Bureau agrees that self-regulating professions must ensure that regulation is not unnecessarily restrictive of freely competitive markets, ${ }^{61}$ and that any professional regulatory scheme must strike the optimal balance between the potential benefits of both competition and regulation. ${ }^{62}$

Rhode argues that increased competition between lawyers and non-lawyers is likely to result in lower prices, greater efficiency and increased consumer satisfaction, ${ }^{63}$ and therefore restrictions on competition should be avoided as much as possible. ${ }^{64}$ While regulation would in some ways restrict competition, it would also aim to ensure competent providers and quality services, greater choice of legal services provider, and more affordable services achievable in part by eliminating the cost of over-training. ${ }^{65}$ This could be achieved through a defined scope of practice and specialized or tiered licensing, which will be discussed further in Part III. The self-regulating legal profession can hardly argue, with respect to paralegal regulation, that regulation is antithetical to access, or attempt to justify a lack of regulation as being in the best interests of the public.

57 Ianni Report, supra note 2 at 13.

$58 \quad$ Ibid at xvii \& 37.

59 Hadfield, "Right-Regulating", supra note 55. See also Rhode, "What We Know and Need to Know About the Delivery of Legal Services by NonLawyers" (2016) 67 S Cal L Rev 429 at 439 [Rhode, "What We Know"].

60 Semple, supra note 21 at 122.

61 Competition Bureau, Self-Regulated, supra note 36 at 133.

62 Ibid at 39.

63 Deborah L Rhode, In the Interests of Justice: Reforming the Legal Profession (New York: Oxford University Press, 2000) at 138 [Rhode, Interests of Justice].

64 Canada, Competition Bureau, Self-regulated Professions - Post-Study Assessment (Ottawa: Industry Canada, 2011) at 4, online: <www.competitionbureau.gc.ca/eic/site/cb-bc.nsf/eng/03407.html>.

65 See Joan Brockman, “'Fortunate Enough to Obtain and Keep the Title of Profession': Self-Regulating Organizations and the Enforcement of Professional Monopolies" (1988) 41 Can Public Admin 587 at 600. 


\section{TO REGULATE OR NOT?}

Ontario implemented paralegal regulation over ten years ago, and while other jurisdictions have also grappled with the issue of whether, and if so how, to regulate paralegals, not one is yet prepared to do so. Progress is being made in some jurisdictions, but law societies are generally resistant to the idea of expanding their regulatory reach to govern paralegals as independent providers of legal services, even though law societies' public interest mandate requires that they "address the growing variety of legal needs in a creative and accessible way." ${ }^{66}$ This resistance is indefensible amidst the access to justice problem gripping the country, and particularly in the absence of a ready and viable solution. Indeed, law societies across Canada recognize that there is an access to justice problem, that regulatory innovation is required, and that there is potential for an enhanced role for paralegals to increase access to justice. ${ }^{67}$

This part canvasses the debates, discussions, and concerns of several law societies in Canada concerning independent paralegals and the regulation of alternative legal service providers. The arguments against paralegal regulation are tired and worn. Documenting them, below, makes them seem even more so.

\section{A. Ontario}

Ontario's first attempt at a paralegal regulatory scheme was introduced in 1986. ${ }^{68}$ The proposed legislation to regulate the activities of paralegal agents was pitched as a means for the government to meet its "obligation to the people of this province to enshrine their right to competent, affordable access to the justice system." ${ }^{\prime 69}$ Ianni recognized that access to the legal system is largely dependent on the availability of legal services within the system, ${ }^{70}$ leading the Task Force to recommend a paralegal regulatory model consistent with the public's need for greater access to legal services. ${ }^{71}$ The Law Society of Upper Canada [LSUC], as it then was named, recognized that paralegals can play a useful access to justice role by providing assistance to individuals who are unable or unwilling to hire a lawyer, but argued that increased

66 "LSUC Treasurer's remarks to Convocation at Annual General Meeting February 24, 2010": Law Society of Upper Canada, Gazette, Spring 2011 at 27.

67 Law Society of British Columbia, "Delivery of Legal Services Task Force Final Report", (1 October 2010) at 2, online: $<$ https://www.lawsociety.bc.ca/Website/media/Shared/docs/publications/reports/legalservices-tf_2010.pdf>; Law Society of British Columbia, "Final Report of the Legal Service Providers Task Force", (6 December 2013) at paras 85 92, online: <https://www.lawsociety.bc.ca/Website/media/Shared/docs/publications/reports/Legal-

ServicesProvidersTF_final_2013.pdf $>$ [LSBC Delivery Report 2013]; LSA ADLSC, "Final Report" 2012, supra note 28 at $1 \& 18$; Victoria Rees, "Transforming Regulation and Governance in the Public Interest" (Nova Scotia Barristers' Society, 28 October 2013); Darrel Pink, Nova Scotia Barristers' Society, "Memorandum to Council - Request for Amendments to the Legal Profession Act" (23 September 2016), online: <nsbs.org/council-materials (28 October 2016); Jeff Hirsch, President of LSM, Law Society of Manitoba Communique (February 2010); Law Society of Yukon, "Toward a New Legal Profession Act Policy Paper" (28 November 2011), online:

$<$ lawsocietyyukon.com/forms/policypapernovember2011.pdf> [Yukon Policy Paper].

68 Ontario, Legislative Assembly, Official Report of Debates (Hansard), Bill 42, An Act to Regulate the Activities of Paralegal Agents, 1986, $2^{\text {nd }}$ Sess, $33^{\text {rd }}$ Leg, Ontario, 1986, First Reading (22 May 1986).

69 Ibid at Second Reading (26 June 1986, Terrence O’Connor).

70 Ianni Report, supra note 2 at 13.

$71 \quad$ Ibid 2 at xvii. 
access to justice would not be sustainable unless and until paralegals were governed, like lawyers, by a regulatory body mandated to govern in the public interest. ${ }^{72}$ While this might have been a self-serving argument - the law society took on the role of regulating paralegals who were long viewed as competitors - access to justice was the ostensible rationale for regulation. ${ }^{73}$ The protracted debates that preceded paralegal regulation were marked by opposing views of independent paralegals and the law society's role in regulating them. The government, law society, lawyers and paralegals sparred over the two most contentious issues: choice of regulator and scope of practice. ${ }^{74}$ The law society eventually took on the role of regulator, and paralegal scope of practice was confined to the existing practice areas authorized by law: small claims, provincial offences and Criminal Code summary conviction matters, matters before provincial and federal tribunals, and certain matters pertaining to no-fault motor vehicle insurance. ${ }^{75}$ The focus on advocacy work, the law society argued, was advantageous since there existed a need for advocacy services in these areas. ${ }^{76}$ Paralegals' calls for a scope of practice that included family law (including appearances at Family Court) and solicitors' work such as real estate, wills and incorporations, ${ }^{77}$ went unheeded. Since regulation was implemented for expediency - it simply imposed a regulatory scheme on existing practice areas and legal services that non-lawyers were statutorily authorized to provide paralegal scope of practice has expanded only slightly to include immigration and refugee matters. ${ }^{78}$ Further efforts by paralegals for an expanded scope of practice that includes family law matters were unsuccessful, but the Attorney General and the law society eventually initiated a review of family legal services in late $2016 .{ }^{79}$ Justice Bonkalo, who headed the review, described it as an important opportunity for public interest analysis of the delivery of legal services, and her recommendations stemmed from consideration of what will best serve the interests of the public. ${ }^{80}$ Justice Bonkalo's recommendation that paralegals who obtain a specialized license should be permitted to provide some legal services in family law matters, including assistance with document preparation, legal advice, and representation in mediated negotiations and in court (but not at trial), ${ }^{81}$ was met with fierce opposition. Many family lawyers and others continue to insist that licensed paralegals should only be permitted to provide family law legal services under lawyer supervision. ${ }^{82}$ The LSO has agreed that an expansion of paralegal scope of practice

72 Law Society of Upper Canada, Task Force on Paralegal Regulation, "Regulating Paralegals: A Proposed Approach - A Consultation Paper" (May 2004) at 3, online: < http://www.lsuc.on.ca/media/may1304_paralegal.pdf.>.

73 Ontario, Legislative Assembly, Official Report of Debates (Hansard), $2^{\text {nd }}$ Sess, $38^{\text {th }}$ Leg, (27 October 2005$)\left(1^{\text {st }}\right.$ Reading) (Attorney-General Michael Bryant).

74 The Law Society of Upper Canada, Report to the Attorney General of Ontario on the Implementation of Paralegal Regulation in Ontario, Pursuant to subsection 63.0.1(2) of the Law Society Act (Toronto: LSUC, January 2009 ) at 3.

75 Law Society of Upper Canada, Task Force on Paralegal Regulation Report to Convocation (Toronto: LSUC, September 23, 2004) at paras 73 - 84 [Task Force Report Sept 2004]; Law Society Act, RSO 1990, c L.8, By-Law 4, s 6(1).

76 Ibid at para 74.

77 Ibid at para 40.

78 Immigration and Refugee Protection Act, SC 2001, c 27, s 91.

79 Bonkalo Report, supra note 48 at Recommendation 4.

$80 \quad$ Ibid at Part 4.

81 Ibid at Recommendations 4 and 6.

82 Julie Macfarlane, "A Week of Contradictions: Why I Sometimes Feel Despair About the Profession I Love" (27 April 2016), NSRLP (blog), online: <https://representingyourselfcanada.com/a-week-of-contradictions-why-i-sometimes-feel- 
to include some family law legal services should be pursued to improve access to justice for the public, not to serve the professional interests of either lawyers or paralegals. ${ }^{83}$ A broader paralegal regulatory scheme appears to be on the horizon, and will hopefully result in enhanced legal services delivery.

Justice Bonkalo's review revealed even more evidence of a gap in affordable legal services and a need for access to legal assistance ${ }^{84}$ for the majority of litigants who are self-represented in family court. Ontario's Civil Legal Needs Project concluded that access to resources in family law and the resolution of family law problems for low and middle-income Ontarians is a priority, and that addressing the gap in services requires a range of services from all partners in the civil legal system. ${ }^{85}$ Like Ianni's Task Force did more than twenty-five years earlier, ${ }^{86}$ the Family Legal Services Review recognized the need to increase access to alternative and affordable ways to obtain qualified legal services. ${ }^{87}$

While the protectionist undercurrent has waned somewhat in the more than ten years since paralegal regulation was implemented, it has not disappeared entirely in Ontario. Elsewhere in Canada, strong resistance to regulating paralegals continues.

\section{B. British Columbia}

The role of paralegals has been studied and debated in British Columbia for almost 30 years, but has so far resulted in only a slightly expanded role for supervised paralegals - a role that lawyers did not embrace with any fervor. The Law Society of BC, however, has recognized that a complete reservation of the practice of law to lawyers cannot be maintained, ${ }^{88}$ and that the regulation of paralegals is an important component of access to justice. ${ }^{89}$ In early 2017 , the law society claimed to be poised to recommend legislative changes to adopt some sort of regulatory scheme that will license paralegals. Whether this will usher in an independent paralegal profession in $\mathrm{BC}$ remains to be seen.

History provides a more complete tale. The issue of paralegal regulation and credentialing was first discussed by the Law Society of BC [LSBC] in 1989. At that time, and again in 2003, the LSBC rejected the idea of creating a class of independent paralegals who would provide unsupervised legal services. But a decade later, the law society changed its position, finding merit in allowing clients a choice of service providers for some legal services, as long as those service providers were appropriately qualified and

despair-about-the-profession-i-love/>.; Ontario Bar Association, "Comments on the Family Legal Services Review Report" (15 May 2017) at 22.

83 Law Society of Upper Canada, Access to Justice Committee, "Report to Convocation" (1 December 2017) (Toronto: LSUC, 2017) at para 21 [LSUC, "Report to Convocation" 2017].

84 See Civil Legal Needs, supra note 44 at 57. See also Macfarlane, Final Report, supra note 40.

85 Ibid, Civil Legal Needs.

$86 \quad$ Ianni Report, supra note 2 at 39.

87 Ontario Ministry of the Attorney General, "Expanding Legal Services Options for Ontario Families" (9 February 2016), online: <https://www.attorneygeneral.jus.gov.on.ca/english/family/legal_services_consultation_paper.html>.

88 Law Society of British Columbia Futures Committee, “Towards a New Regulatory Model” (January 2008) at 2, referred to in LSBC Delivery Report 2013, supra note 67 at para 36.

89 Elizabeth Raymer, "LSBC Discontinues 'Paralegals in Court' Pilot”, Canadian Lawyer (12 January 2017), online: $<$ http://www.canadianlawyermag.com/legalfeeds/3631/lsbc-discontinues-paralegals-in-court-pilot.html $>$. Kristin Dangerfield, CEO of Law Society of Manitoba (2016), online: <http://notjustforlawyers.com/kristen-dangerfield/>; Law Society of British Columbia, "Report of the Legal Services Regulatory Framework Task Force" (Vancouver: LSBC, 2014) at para 49 [LSBC Framework Report]. 
regulated to ensure the public is protected from incompetent or unethical service. ${ }^{90}$ The LSBC believed, from an access to justice rationale, that it was essential to start the discussion about defining appropriate areas of practice for any new legal service providers from the perspective of the public's legal needs rather than asking whether anyone other than lawyers should be able to provide legal services, ${ }^{11}$ and concluded that a new class of legal professional should be established to provide advocacy services in Small Claims court and before administrative tribunals. ${ }^{92}$ Supervised paralegals in $\mathrm{BC}$ have gained some footing. In 2012, the law society created a Designated Paralegal Program that allows a lawyer to designate paralegals working under that lawyer's supervision who would be permitted to perform additional duties. ${ }^{93}$ This expanded role for supervised paralegals was designed to provide the public with more choice in obtaining competent, affordable legal assistance. ${ }^{94}$ The law society determined that the public would be better served by having access to the services of a trained and licensed non-lawyer than having to "go it alone." further initiative, the Court Pilot Project [CPP], which ran from January 2013 to late 2015, permitted designated paralegals to appear on certain procedural family law matters in the Supreme and Provincial Courts in some jurisdictions in the province. ${ }^{96}$ The project was an attempt to ascertain how a limited scope of appearance and practice afforded designated paralegals might work. ${ }^{97}$ But the CPP resulted in no useful evidence because very few lawyers sent their designated paralegals to court, and as a result, it was discontinued. ${ }^{98}$ The numbers reveal an interesting reality. After the CPP had concluded, the LSBC conducted a survey of 481 lawyers who had supervised designated paralegals. ${ }^{99}$ Of the 54 who responded to the survey, not one had sent a designated paralegal to court as part of the family law pilot project. ${ }^{100}$ Macfarlane argues that the LSBC's decision to discontinue the CPP highlights the tension between the self-interest of the profession and the public interest. ${ }^{101}$ Designated paralegals are still permitted, under

90 LSBC Delivery Report 2013, supra note 67 at paras 127-133.

91 LSBC Framework Report, supra note 89 at paras 71 and 72.

$92 \quad$ Ibid at para 74.

93 Law Society of British Columbia, "Designated Paralegal Initiative Improves Access to Lower Cost Legal Services” (13 January 2017), online: <https://www.lawsociety.bc.ca/newsroom/highlights> [LSBC Initiative].

94 LSBC, "Paralegals - Part of the Access to Justice Solution", 2012: No. 3 Benchers' Bulletin, online: $<$ https://www.lawsociety.bc.ca>.

95 LSBC Framework Report, supra note 89 at para 85.

96 LSBC, "Lawyers - Practice Support and Resources - Paralegals" (2013), online:

$<$ http:www.lawsociety.bc.ca/page.cfm?cid=2582>; The Court Pilot Project ended in the Supreme Court on December 31, 2014 and in the Provincial Court on October 1, 2015.

$97 \quad$ LSBC Initiative, supra note 93.

$98 \quad$ Ibid. See also Raymer, supra note 89.

99 Designated Paralegal Survey 2016 results, "Designated Paralegal Initiative Improves Access to Lower Cost Legal Services”, January 13, 2017, online: <https://www.lawsociety.bc.ca $>$ [Designated Paralegal Survey]. There were 11,433 practising lawyers in BC in 2015, online: <http:/www.lawsociety.bc.ca/docs/publications/ar/2015-AnnualReport.pdf $\geq$. The 481 supervising lawyers represent less than five percent (about $4.25 \%$ actually) of practising lawyers in the province.

100 Ibid. The majority of respondents, however, reported a belief that paralegals can play an effective role in court.

101 Julie Macfarlane, “2017 Could be the Year of the Paralegal - Or, Will \#AltFacts Prevail?” (31 January 2017), NSRLP (blog), online: $<$ http://representingyourselfcanada.com/blog/> [Macfarlane, "AltFacts"]. 
lawyer supervision, to provide legal advice and may continue to appear before tribunals if the tribunal permits. ${ }^{102}$

In mid-2015, the LSBC announced that it was preparing to introduce yet another class of legal service provider. ${ }^{103}$ Certified paralegals would be able to deal with family law matters and residential tenancy disputes, and appear as representatives before Small Claims court and administrative tribunals. These are areas unserved or underserved by lawyers - areas that many lawyers find uninteresting or where individuals cannot afford the cost of a lawyer - and where many litigants represent themselves. ${ }^{104} \mathrm{Certified}$ paralegals, the LSBC assured, would be "lower-cost, credentialed and regulated professionals" who will help increase access to the justice system. ${ }^{105}$ Whether certified paralegals would be able to provide legal services independently was unclear, although the LSBC also expressed a desire to move toward Ontario's model of paralegal regulation. ${ }^{106}$ There has not been, however, any further discussion of a certification scheme for paralegals. ${ }^{107}$ The LSBC's lack of any meaningful progress in regulating independent paralegals stands in stark contrast to its recognition a few years ago that it was time to explore a liberalization of the marketplace concerning who can practise law in order to address unmet and underserved legal needs. ${ }^{108}$ At the time, it argued that central to an expansion of the market for legal services was the question of "how wide that door ought to be opened, rather than whether the door need be opened at all." ${ }^{109}$ More recently, the LSBC announced that it is pursuing amendments to the Legal Profession Act to authorize the creation of new classes of regulated legal service providers, which "could include paralegals," to address the need for greater access to affordable legal services. ${ }^{110}$ The law society believes that the best approach is for it to be the single regulator of all legal services providers in the province. ${ }^{111}$

The snail's pace of the law society's progress on a paralegal licensing scheme suggests a lack of meaningful commitment to access to justice in the province and reveals what Macfarlane refers to as an "obvious tension" between the gate-keeping role of the profession and its vested interest in maintaining its monopoly. ${ }^{12}$

\footnotetext{
102 Raymer, supra note 89.

103 "Law Society of B.C. Proposes New Category of Legal Professionals", CBC News (16 April 2015), online: $<$ http://www.cbc.ca/news/canada/british-columbia/law-society-of-b-c-proposes-new-category-of-legal-professionals$1.3035642>$.

104 Ibid.

105 Ibid.

106 Ibid.

107 It is interesting to note that the development of a certification scheme for paralegals was previously recommended, by the Paralegalism Subcommittee in 1989 and again in 2002 by Paralegal Task Force, but rejected: LSBC Delivery Report 2013, supra note 67 at paras 29-34.

108 LSBC Framework Report, supra note 89 at paras 1 and 64.

109 Ibid.

110 Law Society of British Columbia, "Designated Paralegal Initiative Improves Access to Lower Cost Legal Services”, (13 January 2017), online: <https://www.lawsociety.bc.ca/newsroom/highlights $>$.

111 LSBC Delivery Report 2013, supra note 67 at paras 9 and 10.

112 Macfarlane, "AltFacts", supra note 101.
} 


\section{Manitoba}

The Law Society of Manitoba's public interest mandate applies broadly to the delivery of legal services, not strictly to the practice of law, ${ }^{113}$ and the Legal Profession Act therefore contains oversight mechanisms governing non-lawyers and the provision of legal services by them. The Act provides clear authority for a person who is not authorized to practice law in Canada to act as agent on behalf of, or provide legal advice to, another person with respect to provincial offences, and further requires that agents carry liability insurance. ${ }^{114}$ The Act also supports the role of non-lawyers by providing that communication between a person who acts as agent or provides legal advice is privileged in the same manner and to the same extent as communication between a lawyer and his or her client. ${ }^{115}$

The Law Society of Manitoba established a Paralegal Committee in 2010 to determine whether a regulated paralegal profession would improve access to competent, affordable legal services, particularly in family law matters, without compromising public protection. ${ }^{116}$ This led to consideration of an accreditation model but only for paralegals who work under lawyer supervision. ${ }^{117}$ Despite the law society's recognition that non-lawyers "might have a role to play"118 in addressing the access to justice problem, there has not yet been any progress on the matter. The law society acknowledges, though, that improving the way in which it regulates the profession would improve the delivery of legal services. ${ }^{119}$ Pending regulatory changes might just lead to an expanded role for paralegals.

\section{Nova Scotia}

Regulatory changes in Nova Scotia appear set to alter the provision of legal services and expand the role of paralegals in that province. The Barristers Society in 2013 adopted a strategic framework to transform regulation of the delivery of legal services, guided by two priorities: regulating in the public interest and enhancing access to legal services and the justice system. ${ }^{120}$ These priorities are reflected in regulatory objectives adopted in 2016. ${ }^{121}$ Recent revisions to Nova Scotia's Legal Profession Act will expand the society's role. Its new purpose will be to uphold and protect the public interest in the practice of law and the delivery of legal services. ${ }^{122}$ Darrel Pink, Executive Director of the Barristers Society, argues that this new purpose imposes on the society an obligation to enhance access to legal services. ${ }^{123}$ The Barristers Society recognizes that it needs to expand the availability of legal services by a variety of

113 The law society's duties, however, are more narrowly directed to regulating the practice of law: Legal Profession Act, CCSM c L107, as amended, s 3.

114 Legal Profession Act, CCSM c L107, s 40(1)(c); Agents Bonding and Insurance Regulation, Man Reg 105/90, ss 15-16 stipulate that an agent must have insurance coverage for errors, omissions and negligence of $\$ 100,000 \mathrm{minimum}$.

115 Legal Profession Act, CCSM c L107, s 41. These provisions were added in 2005: SM 2005, c 37, Sch. A, s 155.

116 Hirsch, supra note 67 at 1.

117 Ibid at 3.

118 Dangerfield, supra note 89.

$119 \mathrm{Ibid}$. In late 2015, in an effort to address access to justice concerns, the LSM adopted entity regulation: Bill 19, The Legal Profession Amendment Act, $4^{\text {th }}$ Sess, 40 ${ }^{\text {th }}$ Leg, Manitoba, 2016, (royal assent 5 November 2015).

120 Nova Scotia Barristers' Society, FAQs \& Glossary, 2014 at <http://nsbs.org/faqs-glossary>.

121 Nova Scotia Barristers' Society, “Legal Services Regulation Update” Issue 5 (NSBS, April 2016) at 3.

122 Pink, supra note 67.

123 Ibid. 
means while ensuring that the public is protected from poor quality and incompetent service providers. ${ }^{124}$ This includes creating and regulating a new class of non-lawyer legal service provider, and paralegals will be permitted to provide limited-scope legal services. ${ }^{125}$ Paralegals' expanded scope of practice is yet to be determined, and it is not clear whether they will be allowed to provide legal services independently. ${ }^{126}$ Recognition of a role for non-lawyer legal service providers reflects a major change in lawyers' attitudes over the past two decades. A 1998 survey was conducted to gather a statistical profile of lawyers' attitudes towards both supervised and independent paralegals, and their role in the delivery of legal services in Nova Scotia. Over one-third of all law firms in Nova Scotia were surveyed. Fifty percent of those firms responded. All were of the view that independent paralegals would encroach upon a lawyer's business and would erode standards of practice. On the issue of the regulation of independent paralegals, almost half of the respondents opposed the idea of regulation. ${ }^{127}$

\section{E. Saskatchewan}

The extent of the non-lawyer legal services market in Saskatchewan is currently being studied. In April 2016, the Ministry of Justice and Law Society initiated a joint project to explore the possibility of expanding the scope of non-lawyer legal service providers, ${ }^{128}$ with a goal to provide greater access to legal services. ${ }^{129}$ A Legal Services Task Team has been appointed to examine the possibility of allowing nonlawyers to provide some legal services. ${ }^{130}$ This joint project contemplates a range of possibilities for nonlawyer legal services including both expanding the scope of paralegals working under the supervision of lawyers and creating a new class of legal service technicians who would be permitted, with training, to provide some legal services independently. ${ }^{131}$ Both the Ministry and law society acknowledge that not all legal services need to be provided by a lawyer. ${ }^{132}$ They also recognize that having some assistance from a paralegal or legal technician would be better than no assistance, ${ }^{133}$ and that non-lawyer legal service

124 Ibid.

125 Ibid. See also Nova Scotia Barristers Society, "Transforming Regulation: Legislative Changes" (Fall 2016) 35:2 The Society Record at 13, online: <www.nsbs.org> [NSBC Transforming]; Nova Scotia Barristers Society, "Legislative Changes Required for Legal Services Regulation in Nova Scotia" (November 2016) 7 The Society Record, online: $<\mathrm{http} / /$ nsbs.org $>$.

126 NSBC Transforming, supra note 125.

127 Paula Pevato, "Should Law Societies 'Prosecute the Hell' Out of Indepdent Paralegal Firms?” (1991) 7 J L \& Soc Pol'y 215 at $243-247$.

128 Law Society of Saskatchewan, "Survey - Expanding the Responsibilities of Non-lawyer Legal Service Providers - Open Until May 12, 2016” (21 April 2016), Legal Sourcery (blog), online <http://www.lawsociety.sk.ca/>.

129 Law Society of Saskatchewan, "Consultation Paper: Expanding the Classes of Legal Service Providers in Saskatchewan”, (21 April 2016) at 1, online: <www.lawsociety.sk.ca/for-lawyers-and-students/legal-research/newsarchives.aspx $>$ [LSS Consultation].

130 Government of Saskatchewan, "Legal Services Task Team Appointed" (5 May 2017), online:

$<$ https://www.saskatchewan.ca/government/news-and-media/2017/may/05/legal-services-task-team>. The team's recommendations about the appropriate role, if any, of non-lawyers in the provision of legal services are expected in the spring of 2018.

131 LSS Consultation, supra note 129.

132 Ibid at 2-3.

133 Ibid. 
providers might increase the affordability of legal services. ${ }^{134}$ But there appears to be another impetus to act that takes into account the interests of the profession and its desire to maintain control over any regulatory changes to come. The law society insisted, when it launched the joint project, that being proactive will result in the best possible outcome for the Saskatchewan public, the legal profession and other service providers, and that if the law society does not engage with these regulatory changes, it might be forced to change "in ways that might not consider stakeholder interests and concerns."135

\section{F. Quebec}

The paralegal profession in Quebec is not regulated. ${ }^{136}$ Quebec's Association of Paralegals is seeking regulation similar to Ontario's model. ${ }^{137}$

\section{G. Yukon}

A 2004 study of legal services provision in the Yukon, NWT and Nunavut revealed a significant lack of representation in a wide range of family and other civil law matters and a need to expand the role of Indigenous courtworkers - non-lawyers who assist Indigenous persons involved in the legal system across the northern jurisdictions in conjunction with an expanded role in Justice of the Peace courts. ${ }^{138}$ Since a common constraint identified by all courtworkers was a lack of training in procedural and substantive legal issues, ${ }^{139}$ a significant increase in courtworker training, leading to certification for a specific role, was proposed as a way to address areas of unmet need. ${ }^{140}$

The Law Society of Yukon and the government have worked to develop new legislation that will reportedly provide effective and enhanced regulation of legal services, including non-lawyer legal service provision. ${ }^{141}$ The law society has identified "increasing concerns" about access to justice and the availability and affordability of legal services. ${ }^{142}$ It recognizes that the public interest must be paramount,

134 Brea Lowenberger, "Recommendations from Dean's Forum Becoming a Reality: Law Society and Ministry of Justice seeking feedback on expanding the responsibilities of non-lawyer legal service providers in Saskatchewan", (17 May 2016), online $<$ https://1sslib.wordpress.com/2016/05/17/recommendations-from-deans-forum-becoming-a-reality-lawsociety-and-ministry-of-justice-seeking-feedback-on-expanding-the-responsibilities-of-non-lawyer-legal-serviceproviders-in-saskatchew/>.

135 LSS Consultation, supra note 129 at 3.

136 "How to Become a Paralegal in Quebec", online: <www.paralegaledu.org/quebec/>.

137 Jennifer Brown, “Quebec Paralegals Want Recognition from Barreau”, Canadian Lawyer (19 November 2013), online: $<$ http://www.canadianlawyermag.com/legalfeeds/1795/quebec-paralegals-want-recognition-from-barreau.html $>$. The APQ has met with the government and is working on a written submission to be presented to the Minister of Justice and Attorney General of Quebec: Association des Parajuristes du Quebec, online: <http://www.parajuristequebec.ca/page1739698>. The meeting was held on June 1, 2016. Article/notice translated:

$<\mathrm{https}$ //translate.googleusercontent.com/translate_c?depth=1\&hl=en\&prev=search\&rurl=translate.google.ca\&sl=fr\&sp= nmt4\&u=http://www.parajuristequebec.ca/\&usg=ALkJrhhdXoZGtZN27dxa6nxZA-yD4p42JQ>.

138 Pauline de Jong, Government of Canada, Department of Justice, Legal Service Provision in Northern Canada Summary of Research in the Northwest Territories, Nunavut, and the Yukon (Government of Canada, 9 December 2004) at para 6.4, online: < http://www.justice.gc.ca/eng/rp-pr/aj-ja/rr03_la15-rr03_aj15/index.html>.

139 Ibid at para 6.2 .

140 Ibid at para 14.3.

141 Yukon Policy Paper, supra note 67 at $11 \& 31$.

142 Ibid at 1. 
and that the legal profession must evolve to increase access to legal services. ${ }^{143}$ The law society believes that new legislation governing the legal profession should not be limited to regulating the practice of law by lawyers only, ${ }^{144}$ and insists that there must be flexibility in the legislation to allow for the creation of other categories of members, such as paralegals, who can engage in designated aspects of the provision of legal services. ${ }^{145}$ The Yukon government tabled a new Legal Profession Act in October 2017 to update and modernize regulation. ${ }^{146}$ It is yet to be determined if any revisions to the governing legislation will provide for increased access to legal services through courtworkers and independent paralegals.

\section{H. Northwest Territories}

There is no formal regulation of paralegals in the Northwest Territories or Nunavut. The Canadian Bar Association argues that the problem of access to justice is amplified in the Northwest Territories because of distinct challenges such as geography, cultural and language barriers, limited communications infrastructure, and limited access to both private and legal aid counsel. ${ }^{147}$ The Law Society of NWT is considering an expanded role for non-lawyers to address the access to justice problem. In 2014, the Access to Justice Committee undertook to lead and coordinate initiatives to improve and promote access to justice across the territory. ${ }^{148}$ Part of the Committee's mandate was to identify barriers that reduce access to justice and recommend new responses to those barriers that, it has reported, might include alternative and/or innovative models of legal service delivery. ${ }^{149}$ Identified barriers to accessing to justice include a lack of affordability of lawyers, a scarcity of lawyers, inadequate resources for self-represented litigants facing a complicated justice system, and a lack of "truly independent, impartial, well-trained justice workers in smaller communities." 150

\section{Alberta}

The Law Society of Alberta has identified access to justice concerns and a growing public demand for more affordable legal services as two drivers for change, and in the fall of 2017 began to seek input on potential amendments to the Legal Profession Act. ${ }^{151}$ In language that might be interpreted as opening the door to licensed paralegals, the law society argues that a stable democratic society requires access to institutions and services that include dispute resolution, and that Albertans need access to services that help maintain stability and preserve the rule of law. ${ }^{152}$ But it does not appear that any measures to increase access to justice will involve the regulation of paralegals. Despite the law society's ostensible commitment

143 Ibid at 2-3.

144 Ibid at $5 \& 30$.

145 Ibid at 31.

146 Government of Yukon, News Release,17-216, online: <http://www.gov.yk.ca/news/17-216.html>.

147 Canadian Bar Association-NT, “Access to Justice Committee”, online: <http://cbant.org/Sections/About-CBA-NWTCommittees/Access-to-Justice-Committee>.

148 Northwest Territories Access to Justice Committee, "Terms of Reference" (24 April 2014 as amended 24 June 2014), online: < https://ajrndotco.files.wordpress.com/2016/06/tor-committee-final.pdf>.

149 Ibid.

150 Law Society of NWT, Access to Justice - Survey Results (21 April 2015) at 2 \& 5, online: $<$ https://ajrndotco.files.wordpress.com/2016/06/survey-results-report-april-21.pdf $>$.

151 Law Society of Alberta, online: <www.lawsocietylistens.ca/profession>.

152 Ibid. 
to innovation in legal service delivery, there does not appear to be contemplation of a role for licensed independent paralegals. The law society reports that it is seeking legislative amendments to permit lawyers to expand the scope of legal services delivery, so that lawyers can develop new ways to deliver legal services, better address unmet legal needs, and respond better to the everyday legal needs of Albertans. ${ }^{153}$

The Law Society of Alberta previously rejected the idea of regulating independent paralegals because, it claimed, the province's growing independent, non-lawyer legal services industry already meets consumers' need and demand for low-complexity, low-risk legal services. ${ }^{154}$ The law society purports to be committed to access to justice, ${ }^{155}$ but does not view regulation of paralegals as a means to increase access to legal services. ${ }^{156}$ A 2012 study by the law society exploring the alternative delivery of legal services found that independent non-lawyers are subject to consumer protection legislation and market forces, and that consumers are generally happy with the legal services provided. ${ }^{157}$ The law society placed a great deal of emphasis on consumer choice, and has no interest in regulating non-lawyers. ${ }^{158}$ The Law Society of Alberta sees its role as a narrow one - to protect the public when they engage a lawyer, not to protect consumers from freely made choices in accessing legal services, and not to regulate nonlawyers. ${ }^{159}$ Perhaps the LSA's position stems from the difficulty in trying to rein in the entrenched nonlawyer legal services industry. The LSA acknowledges that there are no client protections in place for independent non-lawyer legal service delivery and that unregulated providers do not necessarily provide quality services. ${ }^{160}$ Further, the law society has limited ability to prosecute non-lawyers for unauthorized practice given the Legal Profession Act does not contain a clear definition of the practice of law. ${ }^{161}$ Critics, however, argue that by foisting the burden of policing potentially unscrupulous agents on the often-low income clients they serve, one legal problem snowballs into several. ${ }^{162}$ Low and middle-income Albertans "are desperate for affordable legal assistance" and agents are increasingly filling the demand. ${ }^{163}$ Heather White and Sarah Burton argue that it would make more sense to try and prevent the practice of unscrupulous agents in the first place, and that the need to keep costs low does not justify a complete void in regulation or oversight. ${ }^{164}$ They acknowledge that regulation might raise barriers to justice, but argue that regulation also has obvious benefits. ${ }^{165}$ The law society acknowledges its regulatory responsibility to

153 Law Society of Alberta, “Amending the Legal Profession Act: Key Features" (October 2017), online: $<$ www.lawsocietylistens.ca>.

154 LSA ADLSC, "Final Report" 2012, supra note 28 at 16-24. Between 2000 and 2009 the independent non-lawyer legal service industry in Alberta increased by 230\%: at 15.

155 Ibid at 3.

156 Ibid at 23-24.

157 Ibid at 18.

158 Ibid at 23.

159 Ibid at $1-2$.

160 Ibid at $18 \& 22$.

161 Ibid at $2 \& 25$.

162 Heather White \& Sarah Burton, "Agent Regulation: The Case of Emmerson Brando (AKA Arturo Nuosci, AKA Maverick Austin Maveric, AKA Landon Emmerson Brando)" (15 June 2015), ABlawg (blog), online: $<$ http://ablawg.ca $>$.

163 Ibid.

164 Ibid.

165 Ibid. 
facilitate innovation that supports accessibility to legal services while protecting the public interest, and not to hinder progress in that regard. ${ }^{166}$ But White \& Burton argue that the law society needs to ensure that agents have good character and enough training to pass a licensing exam that, they argue, will help reduce the disparity between the quality of justice for the wealthy and the quality of justice for those with a lower income. ${ }^{167}$ In choosing a representative, White and Burton insist, members of the public need some measure of comfort that their agent is ethical and competent. ${ }^{168}$ They further argue that the law society is the only feasible regulatory body to govern non-lawyer agents. ${ }^{169}$

\section{A CASE FOR PARALEGAL REGULATION}

A successful argument in favour of regulating paralegals as independent providers of legal services can be made, for three main reasons. First, non-lawyers already provide a wide range of legal services in Canada. Second, the relationship between non-lawyer legal services provision and greater access to justice has long been recognized, and some sort of paralegal regulatory scheme has been advocated for. Third, evidence reveals that paralegal regulation in Ontario has been successful in making legal services more accessible, and that licensed paralegals are at least as capable as lawyers of providing legal services. Each of these will be addressed in turn, followed by brief comments on a paralegal regulatory model.

\section{A. Authorized Non-Lawyer Practice}

Non-lawyers already provide a range of legal services in Canada - services that require the application of legal principles and legal judgment ${ }^{170}$ - independent of lawyers and lawyer supervision. The statutes that govern the legal profession in Canada contain exceptions to the practice of law and exemptions for non-lawyers to engage in practice-of-law activities. Other statutes, regulations, and rules of practice and procedure also authorize an array of non-lawyer legal service provision across the country. Such legislative authority has created three main categories of non-lawyer legal services providers. In the first category are those who may only work under the supervision of lawyers - such as legal assistants, inhouse paralegals, law clerks, and articling and law students. The second category includes a range of paraprofessionals who provide legal assistance, advice and representation independently and are not subject to formal regulation by a law society or any other professional association. Some, but not all, of these paraprofessionals provide legal services directly to the public, and for a fee. They are known as court and tribunal agents, consultants, worker and employer advisors and advocates, trade union representatives, corporate employees, Indigenous courtworkers, police officers, IP agents, and others. In the third category are regulated non-lawyers - Ontario's paralegals, federal immigration consultants, and other professionals such as insurance adjusters, real estate agents, notaries public, land surveyors, and chartered accountants - who provide legal services in the ordinary course of carrying on their professional activities. ${ }^{171}$

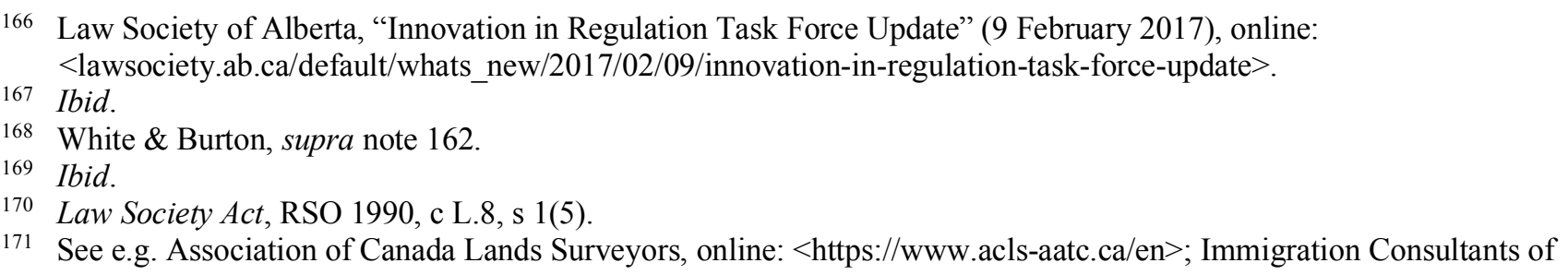


Several years before paralegal regulation was implemented in Ontario, the Ontario Court of Appeal found the absence of any regulatory control over non-lawyer representatives had become "particularly problematic" 172 and that unregulated representation by agents who were not required to have any particular training or ability invites miscarriages of justice. ${ }^{173}$ The same court subsequently opined that a lack of regulation created a gap in consumer protection. ${ }^{174}$

Statutory authorization of the provision of legal services by non-lawyers exists across the country. A brief overview of the activities of court and tribunal agents and other representatives provides a glimpse into the spectrum of non-lawyer legal services provision in Canada. Agents are permitted to represent parties in small claims and other civil matters before certain courts, and in matters involving highway traffic and other provincial offences. ${ }^{175}$ The Criminal Code allows non-lawyer agents to represent persons charged with summary conviction offences, where the term of imprisonment upon conviction is not more than six months, and to examine and cross-examine witnesses as agent for either the defendant or prosecutor. ${ }^{176}$ It is common for RCMP and other police officers to appear as agents for the Crown in some jurisdictions, particularly Alberta, Saskatchewan and the territories. ${ }^{177}$ Indigenous courtworkers advocate on behalf of Indigenous peoples before the courts in most provinces and the territories. ${ }^{178}$ Courtworkers

Canada Regulatory Council, online: $<$ http://iccrc-crcic.info $>$; Insurance Council of British Columbia, online:

$<$ http://www.insurancecouncilofbc.com; Society of Notaries Public, online: $<$ http://www.notaries.bc.ca $>$; Saskatchewan

Real Estate Commission, online: <http://www.srec.ca $>$; Manitoba Securities Commission, online:

$<$ http://www.mbrealestate.ca>; Association of Nova Scotia Land Surveyors, online: <http://www.ansls.ca>; Online:

$<\mathrm{http}: / /$ realestateagentlicences.com/licensing/prince-edward-island $>$. NWT, Municipal and Community Affairs, online:

$<$ http://www.maca.gov.nt.ca/en/services/consumer- affairs $>$.

$172 R v$ Romanowicz (1999), 45 OR (3d) 506 (CA) at para 2.

173 Ibid at paras $88 \& 89$.

174 Elliot v Chiarelli (2006), 83 OR (3d) 226 (ONSC) at para 45.

175 Territorial Court Civil Claims Rules, NWT Reg 122-2016, s 22(20); Small Claims Rules, BC Reg 261/93, R 7; Small Claims Act, 1997, SS 1997, c S-50.11, as amended, ss 7.1 \& 29. (This Act will be replaced by Small Claims Act, 2016, and specifically ss 12 and 33 (Sask Legislative Assembly, Bill 28)); Public Legal Education and Information Service of New Brunswick, Small Claims Court: A Guide for Claimants, Defendants and Third Parties (March 2014), online: $<$ http://www.legal-info-legale.nb.ca/en/uploads/file/pdfs/Small_Claims_EN.pdf $>$; New Brunswick Regulation 2012-103 under the Small Claims Act (OC 2012-383), s 27; Small Claims Court Act, RSNS 1989, c 430, as amended, s 16; Nova Scotia Provincial Court Rules, Rule 1.1 (effective Jan 1, 2013), online:

$<\mathrm{http}: / /$ www.courts.ns.ca/Provincial_Court/NSPC_criminal_rules_forms.htm $>$; Supreme Court of Prince Edward Island, Rules of Civil Procedure, Rule 74 (Small Claims Section), ss 4.01, 4.02, 7.01, 9, 10.01, online:

$<$ http://www.courts.pe.ca/supreme/index.php?number=1003816>; Highway Traffic Act, RSPEI 1988, c H-5, s 264.3(4); Code of Civil Procedure, CQLR C-25.01, ss 88 \& 542; Rules of the Supreme Court of the Northwest Territories, NWT Reg 010-96, s 7(4); Supreme Court of Yukon, Summary Conviction Appeal Rules, 2009, SI/2012-64, s 2(1); See also Ambrosi v Duckworth, 2011 BCSC 1582 (CanLII).

176 Criminal Code, RSC 1985, c C-46, as amended, ss 785, 800(2), 802(2) \& 802.1. Provincial legislation also allows unlicensed individuals to provide legal services in summary conviction matters: Law Society Act, RSO 1990, L.8 s 62, By-Law 4, Part 1, s 6 and Part V.

177 Hearing Office Bail Hearings (Re), 2017 ABQB 74, 2017 ABQB 74, at para 8; Sean Trembath, "Could Alberta Judge's Ruling on RCMP Acting as Prosecutors Affect Saskatchewan?", Saskatoon Star Phoenix (21 February 2017), online: $<\mathrm{http}: / /$ thestarphoenix.com>; de Jong, supra note 138 at para 7.1.

178 Government of Canada, Department of Justice, Indigenous Courtwork Program, online: $<\mathrm{http}$ //www.justice.gc.ca/eng/fund-fina/gov-gouv/acp-apc/index.html?wbdisable=true $>$. Indigenous courtworkers do not provide services in PEI, Newfoundland and Labrador, and New Brunswick. 
negotiate settlements with the Crown, enter pleas, speak to sentence, and also provide support, advice, and representation to Indigenous persons in family, juvenile, and civil matters. ${ }^{179} \mathrm{BC}$ 's Court Agent Act entitles any registered voter in a judicial district to appear in Provincial or Supreme Court as "the attorney and advocate" of any party to a proceeding in that court, in locations where there are less than two members of the law society in actual practice. ${ }^{180}$

Non-lawyers may also represent parties before provincial, territorial and federal administrative tribunals in a range of practice areas including human rights, property assessments, liquor licensing, professional discipline, residential tenancy, industrial relations, trade-marks, patents, veterans' pensions, international trade, transportation, and workers' compensation. ${ }^{181}$ Indeed, in workers' compensation appeals alone in many jurisdictions, the majority of representatives are non-lawyers. ${ }^{182}$

The Supreme Court of Canada has held that statutory authorization of non-lawyer roles before administrative tribunals is consistent with the purpose of such administrative bodies, which is to facilitate access, decrease the formality of hearings, and acknowledge the expertise of other classes of people. ${ }^{183}$ The general rule is that parties appearing before adjudicative tribunals are entitled to representation from an agent of their choosing, ${ }^{184}$ and it is a tribunal's refusal to allow a party to be represented by legal counsel (as in a lawyer) that generates much of the litigation on the issue of representation. ${ }^{185}$

\section{B. Connection Between Non-Lawyer Legal Service Provision and Access to Justice}

The connection between an increased role for non-lawyer legal service provision and greater access to justice has long been recognized and some form of regulation has long been advocated for. Rhode argues

179 James C Hathaway, "Native Canadians and the Criminal Justice System: A Critical Examination of the Native Courtworker Program" (1984 - 1985) 49 Sask LR 201 at 217-219; de Jong, supra note 138 at paras 6.3 \& 6.4.

180 Court Agent Act, RSBC 1996, c 76.

181 See e.g. British Columbia, Human Rights Tribunal, Annual Report for fiscal year April 1, 2015 - March 31, 2016, (Vancouver: BCHRT, 2016) at 8 online: $<$ http://www.bchrt.bc.ca/shareddocs/annual_reports/2015-2016.pdf $>$; Assessment and Planning Appeal Board Regulation, NB Reg 84-59, s 6; Paramedics Act, SNS 2015 c 33, ss 56 \& 70; Liquor Act, SNWT 2007, c 15, ss 1 \& 8(2)-(3); Residential Landlord and Tenant Act, SY 2012 c 20, s 80(3); Veterans Review and Appeal Board Act, SC 1995, c 18, s 35; Canadian International Trade Tribunal Act, RSC 1985, c 47 (4th Supp), s 31; Transportation Appeal Tribunal of Canada Act, SC 2001, c 29, s 15(3); Status of the Artist Act, SC 1992, c 33, s 19(3); Trade-marks Act, RSC 1985, c T-13, s 28(2); Trade-marks Regulations, SOR/96-195, s 18; Patent Act, RSC 1985, c P-4, s 15; Patent Rules, SOR/96-423, s 12(a).

182 Alberta, Workers' Compensation Appeals Division, Annual Report 2015-16 (Edmonton: Appeals Commission, 2016) at 11, online: <https://www.appealscommission.ab.ca/Website\%20Documents/AC\%20AnnualReportFinal.pdf $>$; Saskatchewan, Workers' Compensation Board, Annual Report 2016 (Regina: WCB, 2016) at 14, online: $<$ http://www.wcbsask.com>; Nova Scotia, Workers' Compensation Appeals Tribunal, Annual Report for the Year Ending March 31, 2017 (WCAT, 2017) at 8-9, online: <https://wcat.novascotia.ca/annual-reports>; Newfoundland and Labrador, Workplace Health, Safety and Compensation Review Division, Annual Performance Report 2016-17 (Mount Pearl, NL: WHSCRD, 2017) at 27, online:

$<$ https://www.gov.nl.ca/whscrd/publications/annualreports/2016_17_WHSCRD_AR.pdf $>$; Ontario, Workplace Safety and Insurance Appeals Tribunal, 2016 Annual Report (Toronto: WSIAT, 2017) at 49, online:

$<\mathrm{http}: / /$ www.wsiat.on.ca/english/publications/AnnualReport2016.pdf $>$.

183 Law Society of British Columbia v Mangat [2001] 3 SCR 113 at para 56.

184 Thomas v Association of New Brunswick Registered Nursing Assistants, 2003 NBCA 58 at para 10.

185 Ibid at para 11. 
that lawyers are not required to provide all legal services, just as a surgeon is not required to pierce an ear. ${ }^{186}$ Roderick Macdonald expressed the same view well before paralegal regulation was implemented in Ontario, posing the following question: "[W]hy go to a full-service lawyer in a full-service downtown law firm for advice about a standard form contract when a para-legal can deliver the same product more cheaply from a neighbourhood storefront McLaw Office?"187 Others have held a similar view. Over forty years ago, Victor Savino advocated for an expanded role for legal paraprofessionals to deal with the more common or routine legal tasks as part of an expanded legal services delivery team. ${ }^{188} \mathrm{He}$ argued that making more use of trained non-lawyers would reduce the cost of legal services, increase the efficiency of the delivery system, increase community involvement in legal services delivery, and "most importantly, increase the chance that the average Canadian citizen will obtain access to justice and to the justice system when he or she needs it."189

Ontario's first attempt at a regulatory scheme governing paralegals ${ }^{190}$ was described as a solution to the government's "obligation to the people of this province to enshrine their right to competent, affordable access to the justice system." 191 Then-Attorney General Ian Scott argued that the legal profession had created "an all-or-nothing situation, where the client either gets Cadillac service with a lawyer or goes on foot by himself, when in truth Buick service with a paralegal might be entirely adequate and far better." 192 Brian Lawrie, against whom the law society's unsuccessful prosecution for unauthorized practice was a catalyst for implementation of Ontario's paralegal regulatory scheme, argued in favour of paralegal regulation on the basis that "you don't need a neurosurgeon to come and put a stitch in the end of your finger." ${ }^{193}$ In many areas of legal need, the same situation continues to exist today. ${ }^{194}$

The Ontario Court of Appeal has recognized that paralegals play an important role in increasing access to justice. ${ }^{195}$ More specifically, non-lawyer agents are able to competently represent accused persons charged with certain summary conviction offences. ${ }^{196}$ The Ontario Civil Legal Needs Project revealed that people do not need, or want, full legal representation to solve every civil legal issue they encounter, and for some cases, paralegal representation might be the answer. ${ }^{197}$ Woolley and Farrow argue that the need for lawyers for discreet tasks must not become a barrier to new legal service providers providing effective

\footnotetext{
186 Deborah L Rhode, "Policing the Professional Monopoly: A Constitutional and Empirical Analysis of Unauthorized Practice Prohibitions" (1981), 34 Stan L Rev 1 at 88.

187 Roderick A Macdonald, “Let Our Future Not Be Behind Us: The Legal Profession in Changing Times” (2001) 64 Sask L Rev 1 at 18.

188 Savino, supra note 26.

189 Ibid at 347.

190 Bill 42, An Act to Regulate the Activities of Paralegal Agents, 1986, $2^{\text {nd }}$ Sess, $33^{\text {rd }}$ Leg, Ontario, 1986 ( $1^{\text {st }}$ Reading) $(22$ May 1986).

191 Ontario, Legislative Assembly, Official Report of Debates (Hansard), Bill 42, An Act to Regulate the Activities of Paralegal Agents, 1986, $2^{\text {nd }}$ Sess, 33 ${ }^{\text {rd }}$ Leg, Ontario, 1986 ( $2^{\text {nd }}$ Reading, 26 June 1986) (Terrence O'Connor).

192 Ibid.

193 Margot Gibb-Clark, "Debate heating up over paralegals' role”, Globe and Mail (24 January 2000), online: $<$ https://www.theglobeandmail.com/report-on-business/debate-heating-up-over-paralegals-role/article25454027/>.

194 See, for example, MacFarlane, Final Report, supra note 40; Civil Legal Needs, supra note 44.

195 Koliniotis $v$ Tri-Level Claims Consultants, (2005) 257 DLR $4^{\text {th }} 297,201$ OAC 282 (ONCA) at paras 24-25 \& 33.

$196 R$ v Romanowicz, supra note 172 at paras $77 \& 80$.

197 Civil Legal Needs, supra note 44 at 56.
} 
access to the legal system. ${ }^{198}$ According to Devlin, law societies have an obligation to assist in resolving the problems of access to justice, ${ }^{199}$ and should not only permit but also encourage the emergence of paralegal services and to expand the range of legal services that can paralegals may provide. ${ }^{200}$ Devlin argues that concerns about competence, quality of service, and accountability are legitimate but not insurmountable. ${ }^{201}$

\section{Evidence that Paralegal Regulation Has Enhanced Access to Justice}

Most significantly, evidence reveals that paralegal regulation in Ontario has been successful in making legal services more accessible, and that licensed paralegals are at least as capable as lawyers of providing certain legal services. Lord Denning recognized that in matters before domestic tribunals, justice can often "be done... better by a good layman than a bad lawyer."202 Moreover, the law society has touted paralegal regulation as an "important component" of its ongoing commitment to access to justice. ${ }^{203}$ After the first five years of paralegal regulation, Ontario's law society concluded that the regulation had been "effective and efficient." ${ }^{204}$ The law society reported that paralegal clients were highly satisfied with the regulated services they had received, and that consumer protection had been balanced with maintaining access to justice and the public interest had thereby been protected. ${ }^{205}$ In addition, David Morris, who conducted an independent five-year review, also proclaimed the introduction of regulation to be "by any objective measure... an unqualified success." 206 The law society also touted the benefits of paralegal regulation when it successfully argued before the House of Commons Standing Committee on Citizenship and Immigration in 2010 that its paralegal regulatory model provides effective consumer protection in the public interest and licensed paralegals should therefore be recognized as legitimate providers of immigration consulting services. ${ }^{207}$ In celebrating the ten-year anniversary of paralegal regulation in 2017, law society Treasurer Paul Schabas declared that paralegal regulation had improved consumer services

198 Woolley \& Farrow, supra note 32 at 22.

199 Richard Devlin, "Bend or Break: Enhancing the Responsibilities of Law Societies to Promote Access to Justice” (2015) 38 Man LJ 119 at 122.

200 Ibid at 149.

201 Ibid.

202 Enderby Town Football Club Ltd v Football Ass'n, Ltd [1971] 1 All ER 215 at 218 (CA).

203 Laurie Pawlitza, “Treasurer's Message”, Annual Report (Toronto: Law Society of Upper Canada, 2011), See also Thomas Conway, "Message from the Treasurer", Annual Report, (Toronto: Law Society of Upper Canada, 2013), online: <http://www.annualreport.lsuc.on.ca/2013/en/index.html />.

204 Thomas G Conway, “Treasurer's Message”, Law Society of Upper Canada 2012 Annual Report, Performance Highlights, at 2, online: <www.lsuc.on.ca/annual-report/>. See also LSUC Five-Year Review, supra note 182 at 5.

205 Law Society of Upper Canada, Report to the Attorney General of Ontario Pursuant to Section 63.1 of the Law Society Act (June 2012) at 3-4 [LSUC Five-Year Review].

206 David Morris, Report to the Attorney General of Ontario-Report of Appointee's Five-Year Review of Paralegal Regulation in Ontario Pursuant to Section 63.1 of the Law Society Act (Toronto: Ontario Ministry of the Attorney General, Queen's Printer for Ontario, 2012) at Part 4.

207 Law Society of Upper Canada, Submission to the Standing Committee on Citizenship and Immigration re: Bill C-35, An Act to amend the Immigration and Refugee Protection Act (Toronto: Law Society of Upper Canada, November 1, 2010) at paras 8-10 \& 22. See also Immigration and Refugee Protection Act, supra note 59. 
and public protection. ${ }^{208}$ Licensed paralegals were described as "key providers" of access to justice for Ontarians. ${ }^{209}$

These claims of success might understandably be met with some skepticism since most of them come from the regulator itself. As Trebilcock and Evans argue, professional defenders of the self-regulatory status quo inevitably act as judges in their own cause, since the privilege of self-regulation conveys not only a responsibility to serve the general public interest but also substantial market power with which to serve private and professional interests. ${ }^{210}$ But other evidence also points to the success of paralegal regulation. Many tribunals in Ontario report that paralegals excel at paperwork and advocacy in less complex cases. ${ }^{211}$ Other data tells a similar story. Competence and quality, arguably, can be observed through professional discipline complaints. The presumption is that poor quality services and incompetent providers will likely be the subject of complaints filed with the law society. Indeed, the majority of complaints filed concerning lawyers and paralegals in Ontario in each of the past two years were about service issues (failure to serve the client, failure to communicate, failure to account) and integrity (civility, counseling or behaving dishonourably). ${ }^{212}$ The numbers of complaints filed against lawyers and paralegals in the same two years are proportionate to their membership numbers. That is, there has been no higher proportion of complaints filed against paralegals than against lawyers. For the years 2015 and 2016, law society membership has been split approximately $86 \%$ lawyers to $14 \%$ paralegals. ${ }^{213}$ Of the complaints received about licensees, $87 \%$ in 2015 and $80 \%$ in 2016 were filed against lawyers; $13 \%$ in 2015 and $12 \%$ in 2016 and were filed against paralegals. ${ }^{214}$ This data suggests that licensed paralegals are at least as capable as lawyers, or no less capable, in providing legal services, or at least no more likely to attract client complaints. Moreover, in each of the past two years, the top three areas of law identified in complaints received were civil litigation, matrimonial/family, and real estate, with civil litigation matters attracting the most complaints. ${ }^{215}$ It is noteworthy that paralegals' scope of practice excludes the latter two areas of law, and in civil litigation paralegal practice is restricted to small claims matters.

Studies of non-lawyer legal representatives before administrative tribunals and other civil forums in the USA and UK reveal that non-lawyers provide adequate and in some cases better representation than lawyers in a variety of settings, and that specialization and expertise are the most important qualifications that determine the quality of representation. ${ }^{216}$ As a result, Levin argues that there is little evidence to

208 "May 1 Marks 10 Years of Paralegal Regulation" (27 April 2017), Law Society of Upper Canada Gazette, online: $<$ www.lawsocietygazette.ca/paralegal-update/10-years-of-paralegal-regulation/>.

209 Ibid. Comments attributed to LSUC Bencher Cathy Corsetti, past Chair of the Paralegal Standing Committee.

210 Robert G Evans \& Michael J Trebilcock, eds, Lawyers and the Consumer Interest (Toronto: Butterworths, 1982) at xiii.

211 Bonkalo Report, supra note 48 at Part 2.a.iv.

212 Law Society of Upper Canada, 2016 Annual Report, online: $<$ http://annualreport.lsuc.on.ca $>$ [LSUC, 2016 Annual Report].

213 Ibid.; Law Society of Upper Canada, 2015 Annual Report, online: <http://www.annualreport.lsuc.on.ca/2015/en/index.html>.

214 Ibid.

215 LSUC 2016 Annual Report, supra note 212.

216 See e.g. Herbert M Kritzer, Legal Advocacy - Lawyers and Nonlawyers at Work (Ann Arbor: University of Michigan Press, 1989) at 5; Hazel Genn \& Yvette Genn, The Effectiveness of Representation at Tribunals (London: Lord Chancellor's Department, 1989); Richard Moorhead \& Alan Paterson, "Contesting Professionalism: Legal Aid and Nonlawyers in England and Wales” (2003) 37 Law \& Soc’y Rev 765. 
support the legal profession's claims of superiority as compared to non-lawyer representatives in certain legal contexts, and that the public would be better served if more non-lawyer representatives, who are subject to educational and licensing requirements, could provide more legal services to the public. ${ }^{217}$ Levin also argues that while it is not possible to prove, based on existing studies, that non-lawyer representatives are as effective or trustworthy as lawyers working in certain fields, it is also not possible to prove the opposite. ${ }^{218}$

Immigration consultants are regulated non-lawyer representatives authorized to provide Canadian immigration or citizenship advice or representation for a fee or other consideration, and are regulated by the Immigration Consultants of Canada Regulatory Council, a national body. ${ }^{219}$ The issue of immigration consultants' competence was raised by Sean Rehaag's study of the role of counsel in Canada's refugee determination process which found much lower success rates for claimants represented by immigration consultants than by lawyers, leading Rehaag to conclude that access to competent and qualified lawyers is a key determinant of outcomes in life and death refugee determinations. ${ }^{220}$ The study also found that experienced counsel achieved better outcomes than inexperienced counsel, leading Rehaag to conclude that a lawyer's level of experience was an important factor in refugee claim outcomes. ${ }^{221}$ The same trend was found with respect to immigration consultants - that more experienced consultants achieved better outcomes than less experienced consultants, ${ }^{222}$ and that claimants are better off represented by consultants than unrepresented. ${ }^{223}$ Rehaag's study raised concerns about the regulatory scheme, suggesting that the quality of services provided by immigration consultants before the IRB has much to do with the federal government's regulatory approach. ${ }^{224}$ Problems with the regulatory model have long existed. ${ }^{225}$ The government acknowledges that the current system does not adequately protect the public from unscrupulous consultants and a better regulatory system is required. ${ }^{226}$ Rehaag acknowledges that there is a role for professional and competent immigration consultants in increasing access to representation at the IRB by claimants who might not otherwise be able to afford counsel. ${ }^{227}$ His study leads to two conclusions relevant to the issue of the regulation of paralegals: the experience of representatives matters, and the design of the regulatory scheme matters.

217 Leslie C Levin, "The Monopoly Myth and Other Tales about the Superiority of Lawyers" (2014) 82 Fordham L Rev 2611 at 2615.

218 Ibid at 2630.

219 Immigration Consultants of Canada Regulatory Council (ICCRC), online: $<$ http://iccrc-crcic.info $>$. See also Immigration and Refugee Protection Act, SC 2001, c 27, s 91.

220 Sean Rehaag, "The Role of Counsel in Canada's Refugee Determinations System: An Empirical Assessment" (2011) 49 Osgoode Hall LJ 71.

221 Ibid at 92.

222 Ibid at 89-90. This is consistent with previous studies of non-lawyer representatives: See supra note 216.

223 Ibid at 111.

224 Rehaag, supra note 220 at 73 \& 113-114.

225 House of Commons, Standing Committee on Citizenship and Immigration, Starting Again: Improving Government Oversight of Immigration Consultants - Report of the Standing Committee on Citizenship and Immigration (June 2017) (Chair: Boris Wrzesnewskyj) [Standing Committee] at 4-7.

226 Ibid at 33, Recommendations 3 \& 4.

227 Rehaag, supra note 220 at 110-111. 


\section{Regulatory Model}

The quality of legal services has traditionally been a core preoccupation of regulators. ${ }^{228}$ Semple argues that the current professionalist-independent regulatory model should be reformed, with client-centricity as its overarching goal, because client-centricity strives to ensure that clients and would-be clients have access to legal services that are high quality, affordable, variegated, and innovative. ${ }^{29}$

Despite the potential for self-regulation to raise prices through anti-competitive behaviour, Brockman argues that by far the greatest source of the excessive cost of professional services is the result of overtraining. ${ }^{230}$ One regulatory solution that has been proposed, by more than one reform-minded individual, is tiered or specialized licensing. Justice Cory recommended a general license as well as a specialized license for paralegals who wished to appear before specialized tribunals in Ontario. ${ }^{231}$ Specialized licenses were proposed for paralegals appearing before certain tribunals - those with complicated procedures operating in sensitive areas such as labour relations, workplace safety and insurance, and consent and capacity. ${ }^{232}$ Justice Cory argued that it would be difficult for a general licensing process to provide sufficient training for paralegals appearing before specialized boards and tribunals to adequately protect the public. ${ }^{233}$ The law society did not agree, opting instead for a general license only. Recently, however, the idea of a specialized license has gained traction. Justice Bonkalo recommended, among other things, that the Law Society of Ontario create a specialized licence for paralegals to expand their scope of practice to include specified legal services in family law. More particularly, with this specialized license, Justice Bonkalo recommended that paralegals be permitted to provide a complete spectrum of services in prescribed areas of family law that are typically less complex than other areas. ${ }^{234}$ The LSO has agreed to develop a specialized license for paralegals to offer some family law legal services. ${ }^{235}$ In arguing for regulatory reform to increase the competence of immigration consultants and better protect the public, the Standing Committee on Citizenship and Immigration also recommends development of a tiered licensing system in relation to categories of services individual immigration consultants are permitted to provide, with the highest-level license restricted to those who are "sufficiently capable and experienced" to conduct litigation before the IRB. ${ }^{236}$ A major virtue of limited licenses is that they can result in higher quality services, because of specialization, than that provided by general practitioners. ${ }^{237}$ Semple argues that universal licensing makes legal services more expensive and less accessible to the extent that its heavy training requirements exclude service providers who could meet basic client needs at a lower price. ${ }^{238}$

\footnotetext{
228 Semple, supra note 21 at 249.

229 Ibid at 7 and Chapter 9, sections 2,3 \& 4.

230 Brockman, supra note 65 at 599.

231 Cory Report, supra note 24 at $89-98$.

232 Ibid at 25.

233 Ibid.

234 Bonkalo, supra note 48 at Recommendation 4; LSUC, "Report to Convocation" 2017, supra note 83 at para 22.

235 LSUC, "Report to Convocation" 2017, supra note 83 at para 22.

236 Standing Committee, supra note 225, at 33, Recommendation 5.

237 Hadfield \& Rhode, supra note 34 at 1221. This argument could also be made for lawyers, particularly newly licensed lawyers in their first few years of practice, which might be another way to address the access to justice crisis.

238 Semple, supra note 21 at 288.
} 
Rhode argues that there is public interest in increased competition, ${ }^{239}$ and regulation of non-lawyers should balance the public interest in maximizing choice and minimizing harm. ${ }^{240}$ Rhode also argues that if the goal is to protect clients from incompetence, rather than lawyers from competition, then regulation (and not prohibition) makes sense. ${ }^{241}$ Semple further argues that client-centricity requires regulators to understand the net impacts of their interventions on clients, including their upward effect on service price. Regulation "should be pared back where its detrimental effect on price is not outweighed by beneficial effects on quality, choice, or other desiderata." 242 Increased competition between lawyers and non-lawyers is likely to result in lower prices, greater efficiency, and increased consumer satisfaction. ${ }^{243}$

It is significant to note that while the affordability of legal services is a component of access to justice, and a stated rationale for the regulation of paralegals, the Law Society of Ontario does not in any way regulate the cost of paralegal services. ${ }^{244}$ While paralegals have a duty to charge fees that are fair and reasonable, so do Ontario's lawyers. In addition, the professional conduct rules specific to fees and disbursements of both paralegals and lawyers leave much discretion to the service provider. ${ }^{245}$ In this regulatory context, the high cost of lawyers' services is a major reason for the high rate of self-represented individuals and a prominent feature of the access to justice crisis. Further still, there is an institutional mechanism for clients who dispute a lawyer's account - access to an Assessment Officer of the Ontario Superior Court of Justice - but not for clients who dispute a paralegal's account. For paralegals' clients, the LSO advises them to commence an action in Small Claims court. ${ }^{246}$ This does little to address the affordability of paralegals' services, and questions the law society's commitment to access to justice. Given the access to justice rationale for paralegal regulation, any regulatory model must contain some measure of control over the cost of paralegal services. This is not to suggest that all paralegals' services must be less costly than all lawyers' services, but simply to argue that the regulation of paralegals to address current gaps in legal services and unmet needs must not ignore the affordability component of the access to justice problem. Further exploration of how best to regulate the cost of paralegal services is beyond the scope of this paper, but it is an issue that cannot be ignored. ${ }^{247}$

\section{CONCLUSION}

A lack of access to justice is a serious problem in Canada. Law societies must regulate in the public interest. Evidence reveals that non-lawyers are capable of providing quality services in certain practice

239 Rhode, "Perspective", supra note 54 at 209.

240 Ibid at 212.

241 Rhode, "What We Know", supra note 58 at 438.

242 Semple, supra note 21 at 262.

243 Rhode, Interests of Justice, supra note 63 at 138.

244 The law society leaves it to individual paralegals (and lawyers) to set fees based on the services they provide: Law Society of Ontario, "Questions - The Right Legal Professional", online: <www.lsuc.on.ca > Services for the Public > Choosing the Right Legal Professional $>$.

245 Law Society of Ontario, Paralegal Rules of Conduct, Rule 5.01 and Law Society of Ontario, Rules of Professional Conduct, Rule 3.6-1, online: <http://www.lsuc.on.ca $>$.]

246 Law Society of Ontario, "Your Legal Bill - Too High?", online: <lso.on.ca> Protecting the Public > Complaining About a Lawyer or Paralegal $>$.

247 Regulating the cost of paralegal services only would provide law societies another means to restrict and control potential competitors, and herein lies the "fox watching over the chickens" concern: supra note 5 and accompanying text. 
areas and that regulation enhances access to justice, yet over ten years since Ontario introduced paralegal regulation, no other jurisdiction is prepared to do so. The delivery of legal services by non-lawyers, it appears, challenges the dominance of the legal profession. ${ }^{248}$ According to Rhode, it is more difficult for lawyers to claim special status and justify regulatory autonomy when it becomes clear that non-lawyers can effectively perform legal tasks. ${ }^{249}$

The regulation of independent paralegals is a ready solution to insufficient access to justice and the prevalence of unmet legal needs in this country. But there is nothing new in this. The question law societies purport to be grappling with is the same one that guided Ianni's Task Force almost 30 years ago: Whether or not the activities of independent paralegals, properly regulated, can contribute to, not erode, the public's interest in gaining greater access to law. ${ }^{250}$ What is new is that there now exists a viable regulatory model that is addressing the need for increased access to justice and seems to be balancing the concerns about, and the promise of, regulation. Ontario's might not be the ideal model but it is, at least, a good starting point. As Devlin argues, law societies' embrace of paralegals will not require the reinvention of the wheel. ${ }^{251}$

Ultimately, the profession's resistance to paralegal regulation could harm its self-regulating status as resistance hinders progress in meeting the public's need for greater access to justice. As Arthurs, Weisman and Zemans argued decades ago, the legal profession's "preoccupation with preventing the 'socialization' of legal services ... retards the emergence of new areas of practice." ${ }^{252}$ It also retards the emergence of new classes of legal service providers. Pevato argues that law societies across Canada, if they are honestly committed to serving the public interest, should reassess the underlying reasons for their opposition to paralegals, put aside their monopolistic, self-interested views and welcome independent paralegal firms into the business of law. ${ }^{253}$ According to Hadfield, current obstacles to innovation in regulating legal markets "are not problems of knowledge, but problems of politics." 254

Expansion of the legal services market in Canada, through implementation of a regulatory scheme(s) governing independent paralegals, seems inevitable. How that expansion occurs, by regulatory innovation from within the legal profession, or by force from without, is yet to be determined. As Jennifer Bond, David Wiseman and Emily Bates argue, the Canadian justice system urgently requires innovative approaches to the provision of legal assistance. ${ }^{255}$ Law societies' continued inaction with respect to paralegal regulation arguably perpetuates, even exacerbates, the access to justice crisis. The time to regulate is now.

248 Mary Anne Noone, "Paralegals - in the Community’s Interest?" in Julia Vernon \& Francis Regan, eds, Improving Access to Justice: The Future of Paralegal Professionals (Canberra: Australian Institute of Criminology, 1990) 25 at 33.

249 Rhode, "Perspective", supra note 54 at 202-203.

250 Ianni Report, supra note 2 at 14.

251 Devlin, supra note 199 at 149.

252 Arthurs, Weisman \& Zemans, supra note 54 at 164.

253 Pevato, supra note 127 at 249-250.

254 Hadfield, Rules, supra note 42 at 237.

255 Jennifer Bond, David Wiseman \& Emily Bates, "The Cost of Uncertainty: Navigating the Boundary Between Legal Information and Legal Services in the Access to Justice Sector" (2016) 25 J L \& Soc Pol'y at 25. 